\title{
Critical phenomenology and psychiatry
}

\author{
Dan Zahavi ${ }^{1,2} \circledast$. Sophie Loidolt ${ }^{3}$
}

Accepted: 23 August 2021 / Published online: 26 September 2021

(C) The Author(s) 2021

\begin{abstract}
Whereas classical Critical Theory has tended to view phenomenology as inherently uncritical, the recent upsurge of what has become known as critical phenomenology has attempted to show that phenomenological concepts and methods can be used in critical analyses of social and political issues. A recent landmark publication, 50 Concepts for Critical Phenomenology, contains no reference to psychiatry and psychopathology, however. This is an unfortunate omission, since the tradition of phenomenological psychiatry-as we will demonstrate in the present article by surveying and discussing the contribution of Jaspers, Minkowski, Laing, Basaglia, and Fanon-from the outset has practiced critical thinking, be it at the theoretical, interpersonal, institutional, or political level. Fanon is today a recognized figure in critical phenomenology, even if his role in psychiatry might not yet have been appreciated as thoroughly as his anticolonial and antiracist contributions. But as we show, he is part of a long history of critical approaches in psychopathology and psychiatry, which has firm roots in the phenomenological tradition, and which keeps up its critical work today.
\end{abstract}

Keywords Phenomenological psychiatry $\cdot$ Psychopathology $\cdot$ Critical phenomenology $\cdot$ Critical theory $\cdot$ Fanon $\cdot$ Basaglia $\cdot$ Laing $\cdot$ Minkowski $\cdot$ Jaspers

Dan Zahavi

dan.zahavi@philosophy.ox.ac.uk; zahavi@hum.ku.dk

Sophie Loidolt

sophie.loidolt@tu-darmstadt.de

1 Faculty of Philosophy, Radcliffe Humanities, Observatory Quarter, University of Oxford, Woodstock Road, Radcliffe, Oxford OX2 6GG, UK

2 Center for Subjectivity Research, University of Copenhagen, Karen Blixens Plads 8, 2300 Copenhagen, Denmark

3 Department of Philosophy, Technical University of Darmstadt, Karolinenplatz 5, 64289 Darmstadt, Germany 


\section{Introduction}

Recent years have shown an increasing interest in linking phenomenology and critical theory, and in exploring how one might employ phenomenological concepts and methods in critical analyses of social and political issues, say, through a focus on marginalized experiences, the racialized body, or the predetermining and excluding formation of spaces. ${ }^{1}$ For some, this development has at long last made phenomenology become "political" and "critical." Such an assessment would mirror the traditional view of classical Critical Theory according to which phenomenology was from the outset "uncritical": at best, in the sense of a "bourgeois philosophy" that cultivated a "fetishism of knowledge," albeit with an "anti-systematic attitude"; at worst, as promoting a "jargon of authenticity" that fit in well with National Socialist ideology. ${ }^{2}$ One finds a related skepticism among critical theorists when it comes to the method of phenomenology, which is alleged to exhibit a "blindness to the economic-historical production and genesis of the "essential contents,", and which would therefore always remain "sublimely critically alien, that is, in agreement" with the capitalist status quo. ${ }^{3}$ Despite the very different development in France, where prominent figures like Jean-Paul Sartre, Simone de Beauvoir, and Maurice Merleau-Ponty developed fruitful connections between Marxist critique and existentialist phenomenology, this depiction of an "uncritical phenomenology" has in many ways become entrenched as the standard narrative.

In this article, we wish to question this portrayal by highlighting and reconstructing a specific strand in phenomenology that from the very beginning had a critical agenda, and which so far has been rather neglected among those who currently seek to promote a critical phenomenology, namely the tradition of phenomenological psychiatry. ${ }^{4}$ By surveying and reconstructing the history of phenomenological psychiatry as a history of critique at the theoretical, interpersonal, institutional, and political levels, we aim to provide a salient example of how phenomenology from the outset has practiced critical thinking.

The first step in this history is the criticism of reductionist psychiatry that we find in, for instance, Karl Jaspers and Eugène Minkowski. This theoretical criticism of the attempt to reduce mental illness to organic disorders was motivated by a phenomenologically driven interest in and respect for the patient's experiences and existential situation. But the concern for and interest in the patient's lifeworld, and the attempt to explore it further with the help of phenomenological accounts of temporality, spatiality, embodiment and self-experience, eventually made the interpersonal dimension of the therapeutic situation come into view as a topic in its own right. R. D. Laing is a leading representative of this second stage and type of critique, which

\footnotetext{
1 See, for example, works by Ahmed (2006), Al-Saji (2014), Gündoğdu (2015), Günther (2013), Oksala (2016), and Ortega (2016), as well as the collected volume by Weiss, Murphy \& Salamon (2020).

2 Adorno (2013, pp. 3, 27, 214) on Husserl; Adorno (1973) on Heidegger and Jaspers.

3 Bloch (1996, p. 166) on Reinach.

4 The recent landmark publication 50 Concepts for Critical Phenomenology contains no reference to psychiatry and psychopathology. For one of the few exceptions, see for instance Fernandez 2020.
} 
incorporates ethical, political and sociological considerations as well and eventually takes issue with psychiatry as an institution. Laing's book The Politics of Experience and the Bird of Paradise is a paradigmatic example of how the phenomenological approach gradually evolved into critical practice. We complement the discussion of Laing with a brief outline of Erving Goffman's sociological perspective on the psychiatric institution, and then conclude the second part with a discussion of Franco Basaglia, the Italian phenomenological psychiatrist who was the driving force behind the most radical mental health legislation ever passed. A third strand of phenomenological psychiatry adds to the social and institutional critique a concern with colonial power relations. Our focus will here be on Frantz Fanon, who employed phenomenological tools to analyze the "colonized psyche" and strived for a reform of the "colonized psychiatry" - at least until he decided that the system was too recalcitrant and that he had to continue his anticolonial fight by openly joining the Front de libération nationale.

In all these phenomenological approaches, a critical impetus is clearly present. Phenomenological tools and methods offered themselves as appropriate instruments of description, conceptualization, and analysis in the interest in the patient's experience, in the development of psychotherapeutic treatment, and in the rethinking of the institutional framework. This did not prevent the main protagonists from also drawing on other theoretical resources, such as Bergson's philosophy, Lacan's psychoanalysis or Foucault's historical and epistemological analysis. If anything, the phenomenological psychiatrists were all refreshingly unorthodox in their approaches. ${ }^{5}$

\section{Respecting experience and criticizing objectivism: Jaspers and Minkowski}

Phenomenological philosophy is known for its targeted criticism of reductionism, objectivism, and scientism. What might be less well known is that since its inception it has also exerted an influence on empirical science. Experimental psychology and clinical psychiatry were among the first disciplines to take inspiration from Husserl's call to attend to the phenomena in their full concreteness. Already in 1912, Karl Jaspers published a short article outlining how psychiatry could profit from Husserlian phenomenology. ${ }^{6}$ Given the subject matter of psychiatry, this development is hardly surprising. If we consider some of the central experiential categories that are afflicted in different psychopathological conditions, such as the structure of temporal and spatial experience, the demarcation between self and non-self, the experience of one's own body, the unity and identity of self, the relevance of the phenomenological resources is obvious. Phenomenology has provided extensive

\footnotetext{
${ }^{5}$ Foucault himself suggests that his own project, critical theory, and phenomenology are all sharing a critical impetus with regard to their criticism of reason in modernity, and by developing a "complete critique of positivism, objectivism, rationalization, of techné and technicalization" (Foucault 2007, p. 51; cf. also p. 53).

6 Jaspers (1912).
} 
analyses of such topics, and these analyses contain valuable material for any psychiatrist who is interested in understanding the patient's experience. In the following decades prominent psychiatrists in Switzerland, France, and Germany, including, for instance, Ludwig Binswanger (1881-1966), Eugène Minkowski (1885-1972), and Medard Boss (1903-1990) continued this tradition of phenomenological psychiatry and engaged with phenomenology in their practice and research. Let us here focus on the contributions of Jaspers and Minkowski.

Karl Jaspers' (1883-1969) best known contribution to psychiatry is his General Psychopathology from 1913. This milestone contribution, which subsequently appeared in many expanded editions, had a significant impact, both directly and indirectly, on the subsequent development of psychiatry, especially in Germany and the UK. Psychopathology refers to the study of anomalous experience, expression and action. By virtue of its medical nature and roots, psychopathology draws on various natural sciences, including genetics, epidemiology, neurobiology, and neuropsychology. But it also has deep affinities to the humanities and social sciences, in particular philosophy. In what eventually became a book of more than 700 pages, Jaspers passionately defended the need for methodological pluralism, emphasizing the extent to which methods and viewpoints from philosophy had a special value for psychiatry. Philosophical erudition, says Jaspers, fosters a curious and sophisticated attitude of mind, and "only philosophical clarity can make reliable, empirical research possible." 7

In the core sections of his book, Jaspers offered phenomenological expositions of anomalous subjective experiences and disorders of expression and performance. Jaspers did acknowledge that "psychological phenomena" or "psychic events" must also be studied using methods of behavioral description and measures of performance and must be considered in their causal relationship with neural structures and processes. Yet, as he pointed out, what is of interest to psychiatrists qua psychiatrists are never the brain events in themselves, but only these events in relations of correlation or possible causation with what occurs on the conscious level. After all, the only reason brain states assume the importance they do is through their relationship with mental episodes identified on experiential grounds. More specifically, Jaspers was adamant that psychiatry could only progress as a science if it carefully attended to the experiential perspective of the patient.

We find a similar orientation in Eugène Minkowski, who also counts as one of the early founders and principal advocates of phenomenological psychiatry. After obtaining his medical degree in 1909, Minkowski studied philosophy and attended lectures by Pfänder and Geiger, two of Husserl's former students. He eventually became chief psychiatrist at the Sainte Anne hospital, a leading psychiatric hospital in Paris, and in 1927 published La schizophrénie-occasionally appraised as the best clinical work on schizophrenia ever written.

One of Minkowski's central claims was that the psychiatrist in order to offer a proper diagnosis should not merely be concerned with observing, describing and registering the frequency and regularity of the symptoms that are present. Such

\footnotetext{
${ }^{7}$ Jaspers (1963, p. 46).
} 
symptoms, say, florid delusions or hallucinations, present us, in his view, only with the surface of the disorder. They vary from individual to individual and are ultimately secondary and compensatory reactions to the more fundamental core or essence of the disorder. The task of the psychiatrist is to go beyond these scattered surface symptoms in order to grasp the underlying organizing structure of which they are expressions. ${ }^{8}$ Indeed, for Minkowski, any single anomalous mental episode should never be considered in isolation but should be viewed as a condensed expression of a more basic existential alteration. For Minkowski, this more fundamental disorder can be ascribed a pathogenic role. It antecedes, underlies, and shapes the emergence of the diverse symptoms, and may precisely unify what, from a purely descriptive standpoint, may seem to be unrelated or even antithetical symptoms. In the case of schizophrenia, Minkowski took the disorder to involve what he called a fundamental loss of vital contact with reality. ${ }^{9}$ To lose this ability is to lose a basic, non-reflective attunement with the world, with oneself, and with others. It is to lose the ability to "resonate with the world," to be affected by and to act suitably in the intersubjective world. One of the reasons Minkowski became interested in phenomenology was precisely because he thought it capable of uncovering and analyzing this altered structure.

In Minkowski's work, Lived Time: Phenomenological and Psychopathological Studies, published in 1933, we find explicit reflections on the question of whether and how one ought to make use of philosophical phenomenology in clinical practice. As Minkowski observed, there are those for whom the term "philosophical" has pejorative connotations. In his own case, however, insights from phenomenology had been of crucial value for his clinical practice. By employing a phenomenological framework and approach, it had been possible to gain some access to the otherwise unfathomable world of the patient, and thereby been possible to expand psychiatric knowledge. ${ }^{10}$ At the same time, however, Minkowski also emphasized how philosophical phenomenology might learn from its engagement with psychiatry and psychopathology. As he pointed out, some of the relatively abstract phenomenological considerations could not only become more concrete and tangible as a result of their application in psychopathology, but psychopathological research could also lead to a refinement of the phenomenological analyses, insofar as they called attention to specific aspects or dimensions of experience that philosophers had overlooked.

To properly appreciate the importance and critical dimension of Jaspers' and Minkowski's work, it is necessary to understand what they were up against. There is, of course, a different approach in psychiatry, one that to a large extent side-lines psychopathology and the interest in and concern for the experiential life of the patients, and which instead turns to neurology and neurobiology in an attempt to determine the "real" underlying cause of the mental disorders. At its most extreme, the "broken brain paradigm" views mental disorders as the result of malfunctioning

\footnotetext{
${ }^{8}$ Minkowski (1970, pp. 185, 222, 228).

9 Minkowski (1970, p. 227).

10 Minkowski (1970, p. xxxix).
} 
brain mechanisms and neural circuitries. Symptoms reported by the patients, any anomalous experiences, are not reliable indicators of the underlying causes, and if one wishes to study and understand the disorders in question, be it schizophrenia spectrum disorders or mood disorders, one should investigate the brain rather than listen to, let alone speak with, the patient. Jaspers' and Minkowski's person-centered approach to psychiatry can consequently be contrasted with a sub-personal braincentered approach. In classical psychiatry, a central proponent of this approach was Emil Kraepelin (1856-1926). According to Kraepelin, who played a major role in establishing the foundations for the classification of mental disorders, psychiatry was very much to be considered a branch of medical sciences, and its methods should also be those of the natural sciences, i.e., observation and experimentation. Kraepelin was particularly interested in the biological markers of mental illness and is well known for having argued that dementia praecox or what was later termed schizophrenia was a brain disease, one involving severe damage to or destruction of the cortex. ${ }^{11}$

This brain-centered approach is by no means a thing of the past but is increasingly being heralded as the only way that psychiatry can finally obtain its rightful place among the other medical specialties. Within the last decade, this trend has in particular been propagated by the US National Institute of Mental Health in its effort to launch the RDoC (Research Domain Criteria) project as an alternative to the classical DSM (Diagnostic and Statistical Manual of Mental Disorders) system that, from its third revision in 1980, classified mental disorders on the basis of clinical symptoms. Proponents of the RDoC program have insisted that psychiatry should employ the same technologies and neuroscientific methods that have been so successful in other medical disciplines. Mental disorders are brain disorders and research in psychiatry should be driven by neuroscience and the classification of mental disorders be based on a bottom-up approach. As it was stated in an early paper: "the focus for $\mathrm{RDoC}$ is on neural circuitry, with levels of analysis progressing in one of two directions: upwards from measures of circuitry function to clinically relevant variation, or downwards to the genetic and molecular/cellular function that ultimately influence such function." 12

The claim that mental disorders are brain or neural circuit disorders is obviously a reductionist claim. The belief that mental phenomena can simply be understood and explained in terms of neurobiological processes has been criticized repeatedly by phenomenological philosophers with the argument that it fails to do justice to the intentional, phenomenal and normative aspects of the mind. But disregarding such theoretical concerns, there is a more pertinent ethical and therapeutical problem. As lived experiences, psychotic episodes are experienced by the patients as meaningful, as possessing some sense and significance. If that person-level meaning is deemed unimportant or irrelevant for the study of mental disorders, what will that mean for the patient? How will it affect the clinical interaction, if the patient's experiences are dismissed by the psychiatrist as meaningless eruptions of a malfunctioning brain?

\footnotetext{
11 Kraepelin (1913).

${ }^{12}$ Insel et al. (2010, p. 749).
} 


\section{Interpersonal phenomenology and institutional critique: Laing, Goffman, Basaglia}

Whereas the first generation of phenomenological psychiatrists was critical of the objectifying and reifying attitude of biological psychiatry, the second generation expanded the scope of their criticism to also target institutional structures and societal issues and was particularly concerned with the marginalization of the mentally ill.

Consider first the case of R.D. Laing (1927-1989). In his work, Laing was not only drawing on the contributions of earlier generations of phenomenological psychiatrists such as Boss, Binswanger, and in particular Minkowski, whose work Laing praised as "the first serious attempt in psychiatry to reconstruct the other person's lived experience" and as "the first figure in psychiatry to bring the nature of phenomenological investigation clearly into view." "13 Laing also engaged with the philosophical work of figures such as Husserl, Heidegger, Schutz, Merleau-Ponty and in particular Sartre. He co-authored a book on Sartre, and Laing's early book The Divided Self was at the time of its publication in 1960 one of the most accessible introductions to phenomenological ideas in English. ${ }^{14}$

Laing describes his own efforts as both a type of social phenomenology and as a form of existential phenomenology. It is an attempt to study "inter-experience," i.e., the origins of experience in relation, as well as to "characterize the nature of a person's experience of his world and himself." 15 One of the aims of existential psychiatry is to "discard any preoccupations which prevent one seeing the individual patient in the light of his own existence." 16 In fact, and here Laing is very close to Minkowski, the aim is not simply to describe particular experiences, but rather to situate these experiences within the context of the patient's whole being-in-the-world. And as Laing adds, the "mad things said and done by the schizophrenic will remain essentially a closed book if one does not understand their existential context."17

To think that one can somehow obtain a better understanding of another person by translating a personal-level understanding into the impersonal terms of a sequence or system of it-processes, is for Laing nothing but an illusion. ${ }^{18}$ Just as one will never find consciousness by looking through a microscope at brain cells, one will never find persons by studying them as though they were mere objects. ${ }^{19}$ In fact, the idea that an unbiased scientific understanding of the other requires one to be objective in the sense of depersonalizing the person into an "object" of study is a fallacy that has nothing to do with proper science. ${ }^{20}$

\footnotetext{
13 Laing (1963, p. 207).

14 Laing \& Cooper (1964).

15 Laing (1990, p. 15, 17).

16 Laing (1960, p. 6).

17 Laing (1990, p. 17).

18 Laing (1990, p. 22).

19 Laing (1967, p. 20).

${ }^{20}$ Laing (1990, p. 24).
} 
Persons are centers of experience and origins of actions that exist in social fields of reciprocal influence and interaction. We are not self-contained monads but are constantly interacting with others. Our interaction can be validating, confirming, enhancing, but it can also be invalidating, undermining, and constricting. Indeed, the fact that others can play a destructive role follows from our very interdependence. ${ }^{21}$ One way to objectify and dehumanize the other is by invalidating the other's experiences, by labelling them as mad and abnormal, by treating the other as an object-tobe-changed, as someone bereft of agency, as someone who is invaded and controlled by destructive psychopathological mechanisms. ${ }^{22}$ But as Laing then remarks "[P] eople who experience themselves as automata, as robots, as bits of machinery, or even as animals... are rightly regarded as crazy. Yet why do we not regard a theory that seeks to transmute persons into automata or animals as equally crazy?"23

If we are to understand schizophrenia, we need, according to Laing, to consider "the whole social context in which the psychiatric ceremonial is being conducted." 24 Laing does not deny the existence of schizophrenia, but as he writes, the

label is a social fact and the social fact a political event. This political event, occurring in the civic order of society, imposes definitions and consequences on the labelled person. It is a social prescription that rationalizes a set of social actions whereby the labelled person is annexed by others, who are legally sanctioned, medically empowered, and morally obliged, to become responsible for the person labelled. ${ }^{25}$

Laing further claims that the person labelled as insane and forcibly admitted to a mental institution is invalidated as a human being in a more complete and radical manner than anywhere else in society. ${ }^{26}$

Laing's ideas gradually moved him from advocating a more humane psychiatry to questioning the very basis of psychiatry itself. Although he personally disowned the label "anti-psychiatry," his ideas came to provide the intellectual bedrock for the anti-psychiatric movement. ${ }^{27}$ Even after the decline of the anti-psychiatric movement, Laing's ideas continued to be influential in the user movements and came to play a role in the development of therapeutic communities that sought to involve the patients in decision making.

For Laing, a self-critical psychiatrist should recognize to what extent the psychiatric examination and the very classification of a person as a psychiatric patient is an exercise of control and power. ${ }^{28}$ To look and to listen to a patient and to see "signs" of schizophrenia (as a "disease") and to look and to listen to him simply as

\footnotetext{
${ }^{21}$ Laing (1967, p. 29).

22 Laing (1967, p. 30).

23 Laing (1990, p. 23).

24 Laing (1967, p. 86).

25 Laing (1967, p. 100).

26 Laing (1967, p. 101).

27 Crossley (1998, p. 878).

28 Laing (1967, p. 101).
} 
a human being are to see and to hear in two radically different ways. ${ }^{29}$ In the context of therapy, existential phenomenology is the attempt to reconstruct the patient's way of being himself in his world, and in order for that to happen, the psychiatrist must have the plasticity to transpose himself into a strange and alien view of the world, only thus can one arrive at an understanding of the patient's existential position. ${ }^{30}$ Laing is consequently calling for the psychiatrist to employ empathy and put her own "personality into play." Something he repeatedly faults Kraepelin for not having done. $^{31}$

One book often referenced by Laing is Erving Goffman's Asylums. Essays on the Social Situation of Mental Patients and Other Inmates. Goffman's book was published in 1961, the same year as Foucault's Madness and Civilization. Both theorists share much common ground in their focus on how closed disciplinary organizations shape the identity and self-perceptions of the inmates. But whereas Foucault considered how pervasive systems of thought influenced and enabled concrete practices, Goffman focused on microstudies of the concrete encounters between specific individuals. $^{32}$

Goffman (1922-1982) was not trained as a phenomenologist. He was a sociologist who had graduated from the University of Chicago and who belonged to the tradition of symbolic interactionism inaugurated by G. H. Mead. But Goffman's approach was early on described as phenomenological by other sociologists (e.g., Parson 1968), and the fact that his focus was very much on the communicative exchange and face-to-face interaction between embodied individuals who share time and space together makes it natural to compare his work to that of Schutz, who is indeed the phenomenological thinker most explicitly and extensively discussed by Goffman. $^{33}$

Asylums is a participant-observational study of the mental patients at the St. Elizabeth's Hospital in Washington, DC. This was the largest mental hospital in the US, and the very institution where Walter Freeman a few years earlier had started practicing his "transorbital lobotomy," where steel instruments resembling icepicks were hammered into the brain of the patient through the eye socket; a procedure that Freeman eventually promoted as a cure for serious mental illness, chronic pain, insomnia, and nervous indigestion. Posing as an employee of the hospital for a year, Goffman offers a detailed ethnographic study of the patients' social life. The hospital is, to use Goffman's term, a total institution. It is an all-encompassing institution where the normal structures and compartmentalization of daily life have been abolished. Work, recreation, and sleep are all conducted at the same place following a tightly regulated schedule under constant supervision. ${ }^{34}$ Focusing in particular on the effects of coercion and control, Goffman depicts the mental hospital as a thoroughly

\footnotetext{
${ }^{29}$ Laing (1990, p. 33).

30 Laing (1990, p. 34).

31 Laing (1967, pp. 88-89; 1990, pp. 29-31).

32 Hacking (2004, pp. 277-278).

33 For a comparison of Goffman and Schutz, see Smith (2006) and Psathas (1989, pp. 53-78).

34 Goffman (1961, p. 6).
} 
authoritarian system where the patients through processes of humiliation, deprivation, and abuse are stripped of their identity, dignity and self-esteem and forced to "engage in activity whose symbolic implications are incompatible with" their preexisting conception of self. ${ }^{35}$

Although Goffman did not explicitly propose public policy changes in his study, the book became an important source of reference for critics of psychiatric practice and led to modifications of treatment programs through its citation in legal briefs and judge's rulings. ${ }^{36}$ As Weinstein recounts, Asylums was cited in a number of cases at the federal level that established precedents for mental health policy. One of the cases, Wyatt v. Aderholt was a landmark case in the patients' right movement and granted the patients right to privacy, the right to have visitors, to live in humane physical environments and have individualized treatment plans. $^{37}$

Goffman was subsequently criticized for focusing too much on the hospital as a place for the social control of the deviant and abnormal, and for overlooking its therapeutic and rehabilitative goals, but more than any other work by a social scientist, it was Goffman's book that "sensitized psychiatrists and public officials to the antitherapeutic consequences of hospital treatment, the negative effects of labelling on patients' sense of self-worth, and the loss or curtailment of legal rights resulting from institutionalization., 38

Less known than Laing and Goffman, but ultimately far more influential when it came to policy change was the Italian psychiatrist Franco Basaglia (1924-1980). Drawing directly on phenomenology in his theory and practice, he was to give name to what became known as the Basaglia Law, which many consider the most radical mental health legislation ever passed.

After having graduated in medicine in 1949, Basaglia continued studying philosophy and psychiatry, and became increasingly attracted by phenomenological philosophy and by the classical tradition of phenomenological psychiatry. He was particularly inspired by the work of Husserl, Minkowski, Binswanger and by Sartre, whom he met on several occasions. Basaglia considered himself a phenomenologist, and roughly a third of his collected works deal with the application of phenomenology to psychiatry. ${ }^{39}$

In 1961, the same year that saw the publication of not only Goffman's Asylums and Foucault's Madness and Civilization but also of Fanon's Wretched of the Earth-books that Basaglia was thoroughly familiar with, indeed it was Basaglia's wife Franca Ongaro who translated Asylums into Italian-Basaglia left his university position in Padua and took up the directorship of the mental asylum in Gorizia, where he would remain until 1968. In contrast to the university clinics and the

\footnotetext{
35 Goffman (1961, p. 23).

36 Weinstein (1994, p. 349).

37 Weinstein $(1994$, p. 355).

38 Weinstein (1994, p. 364). That the mental hospitals were in need of fundamental improvements is hardly deniable. Whether the ensuing deinstutionalization program-returning the mentally ill to the community for ongoing care-was altogether a good thing is a separate question, since many of the former patients ended up on the streets as homeless.

39 Lovell and Scheper-Hughes (1987, p. 4).
} 
private clinics where research was conducted and psychotherapy performed, the Italian public psychiatry at that time operated under an outdated and heavily stigmatizing mental health legislation. The main function of the mental asylums, which at that time contained almost 100.000 inmates, was to lock away patients considered a danger to themselves or to society. Once inside the asylums, the patients were stripped of their civil rights and the decision on whether and when to release them was entirely up to the director of the asylum. ${ }^{40}$

The asylum in the city of Gorizia, which is situated on the Italian border with Slovenia, contained cages for unruly patients, barred windows, high walls and fences, and the primary "therapy" on offer was electroconvulsive therapy and insulin shock therapy. Many of the patients had been there for years with no prospect of release.

In many ways, the asylum that Basaglia took control over exemplified a nightmarish version of the kind of total institution that Goffman had described; it confirmed his claim concerning its destructive power, and Basaglia was shocked to witness the inhuman treatment and social degradation that the patients were routinely subjected to.

One of Basaglia's first decisions as new director was to limit the use of straitjackets and shock therapy. He also gradually removed fences, gates, and locks. Next, he set about to change the organizational dynamics of the asylum. He introduced a bar, a football pitch, televisions, radios, a hairdresser's salon, and a library, and soon the patients also started to edit and produce their own magazine. In order to address the power relationship between the doctors and patients, Basaglia forbade the doctors to wear their anonymizing white coats, and most importantly, he introduced hospital-wide community meetings chaired by the patients, where they together with the social workers, nurses and doctors could decide on matters related to the daily life of the hospital. ${ }^{41}$

Basaglia was fighting against the segregation and social exclusion of the mentally ill. He was well aware of the fact that phenomenological psychiatry had only changed institutional practices marginally, but phenomenological theorizing had a profound impact on Basaglia's own practice. ${ }^{42}$ In line with Minkowski, Basaglia was of the belief that it was possible to understand the patient's experiential and existential situation, and he specifically referred to Husserl's epoché when describing how one should engage with the patients. ${ }^{43}$ Rather than seeing them through diagnostic categories, as schizophrenic or depressive, the psychiatrists should try to relate to and attend to the patients as unique individuals. To be able to do so, it was necessary with a bracketing of the diagnostic labels, with a suspension of the theoretical framework of psychiatry. ${ }^{44}$ Only by performing a kind of epoché on the very notion of mental illness, only by suspending all the preconceived and stereotypical

\footnotetext{
40 Serapioni (2019).

41 Foot (2015, chap. 8).

42 Lovell \& Scheper-Hughes (1987, p. 7).

43 The most thorough discussion of how the Husserlian epoché can be used by the psychiatrist to gain some understanding of the existential situation of the schizophrenic patient can be found in Blankenburg (1979). See also Zahavi (2021) and Loidolt (2021).

44 Lovell and Scheper-Hughes (1987, p. 8).
} 
conceptions and expectations that one might have regarding the mentally ill, would it be possible to obtain some kind of comprehension of the patient's being-in-theworld. Importantly, Basaglia was not out to deny the reality and existence of mental illness - as he remarked in a lecture given in Brazil in 1979, "Those who say that mental illness does not exist ... are imbeciles"-but he argued that the violence of the asylum system was ultimately more dehumanizing and more destructive of the personal dignity of the patient than the illness itself. ${ }^{45}$ In addition, he urged the psychiatrist to question his own role and the status of the science he represented, and he insisted that a proper assessment of the nature and cause of mental illness would have to include a critical look at the social, institutional, and political parameters. ${ }^{46}$

Basaglia's model of a care community, marked by principles of ethics and democracy, that was first attempted in Gorizia became an inspiration for change in many other psychiatric hospitals in Italy. It had a huge impact on public opinion and eventually also started influencing national law and policy. After Gorizia, Basaglia continued his efforts at the San Giovanni psychiatric hospital in Trieste. When he arrived in 1971, the hospital contained 1200 patients, 800 of which had been committed involuntarily. During the following years, massive changes were effectuated, the hospital grounds were opened to the surrounding city, new community mental health clinics were opened, the patients were permitted entry to the labor market, and, by 1977 , only 130 patients continued to live on the premises. ${ }^{47}$

In 1978, the Italian Parliament then passed Law 180, also known as the Basaglia Law. The law restored the constitutional rights to the mentally ill. Psychiatric patients were from now on to be considered patients like other patients. It contained directives for the abolishment of the entire Italian asylum system and demanded that all current and chronic patients should gradually be discharged and reintegrated into a whole range of community-based services. Acutely psychotic patients could still be hospitalized, but at small psychiatric wards in general hospitals and not in psychiatric hospitals. ${ }^{48}$

\section{Psychiatry, politics, and the colonized self: Fanon}

As the last and most politically active figure in this selection of phenomenological approaches in psychiatry, we want to look at Frantz Fanon (1925-1961). On the one hand, Fanon clearly belongs to the line of critical approaches in psychiatry, as recent publications increasingly emphasize. ${ }^{49}$ On the other hand, he deserves a special mention since he directly relates the interpersonal and institutional critique of psychiatry to a criticism of colonialism. As Fanon argued, colonial domination itself generates pathologies and fundamentally undermines subjects in their constitution

\footnotetext{
45 Quoted in Foot (2015, chap. 2).

46 Serapioni (2019, p. 9).

47 Serapioni (2019, pp. 11-13).

48 Foot (2019, p. 170).

49 Gibson \& Beneduce (2017), Robcis (2020), Luxon (2021).
} 
as relational selves. One famous example of this is Fanon's phenomenological analysis of the "lived experience of the black man" in Black Skin, White Masks. ${ }^{50}$

Like Sartre, Merleau-Ponty, and de Beauvoir, Fanon sees an immediate connection between phenomenological questions and the approaches of Marx, Nietzsche, and Hegel. He draws on a variety of theoretical sources and combines them in an innovative manner. This should not surprise given that he is seeking to understand a phenomenon that has not been addressed before: the experience of racialized subjects in colonial societies and the psychopathological effects of this racialization.

In the course of his psychiatric training, Jaspers had been important for Fanon, as had Lacanian psychoanalysis. Fanon was fascinated by Lacan's attempt to situate the subject socially, linguistically, and symbolically, and he drew heavily on work from Lacan's early phenomenological phase. In his 1951 dissertation in psychiatry, Fanon writes that Lacan's "phenomenology of personality" is characterized above all by two basic ideas: by "relations of understanding that he inherits from Jaspers," and by the idea of "intentionality" through which personal development is revealed in each of its manifestations. ${ }^{51}$ Fanon also appreciated how Lacan in explaining madness, moved from the paradigm of "causality" to that of "motivation" and how he adopted an "intersubjective perspective" that made madness entirely comprehensible within a register of "meaning." 52

In addition to his well-known ties to Sartre, Fanon also discusses Merleau-Ponty and the Gestalt psychologists Gelb and Goldstein, whose work was so central to many of the analyses in Phenomenology of Perception. Fanon, however, always adds a historical as well as political orientation to these phenomenological analyses. It becomes increasingly clear to him that the social dimension of mental disorders points to political, cultural, and historical issues that must also be considered by the psychiatrists.At the same time, human freedom remains central to Fanon. Even if it is interwoven with the social and the somatic, he still considers it of decisive existential and political importance. Fanon is consequently not a theorist who would simply reject biological or neurophysiological explanations of pathologies. ${ }^{53} \mathrm{He}$ is not an anti-psychiatrist who would deny the existence of mental illness or reduce it to socio-political conditions. ${ }^{54}$ Rather, already in his dissertation, he refers to psychosomatic medicine, which draws a dynamic and reciprocal link between the psychical and the physical, and thereby allows for a "holistic approach to the patient" and a "medicine of the person," which can "reach the very heart of the human conflict." 55

Fanon sees his patients as whole persons, as existences situated in a social and political field. Their experienced temporality and their possibility of action is thus existentially embedded in-or alienated from-their historical and socio-cultural

\footnotetext{
${ }^{50}$ Fanon (2008, pp. 89-120).

51 Fanon (2014, p. 59). It is interesting to note that Fanon on the same page rejects the method of Kraepelin.

52 Fanon (2014, p, 61). For Lacan's relation to phenomenology see Schmidgen (2003).

53 See also Fanon's paper "Mental Disorders and Neurological Disorders," which presents a differentiated view on the topic (Fanon 2014, pp. 51-64).

54 Gibson \& Beneduce (2017, p. x).

55 Fanon (2014, pp. 62-63).
} 
situation. This leads Fanon to an understanding of alienation as "the suspension of the existential link to time" and of delusion as a "limit of freedom" where the free choice paradoxically amounts to "removing oneself from history and renouncing action within it." 56 Whatever the underlying neurobiological causes, "all delusional phenomena is [sic] in the end expressed phenomena, meaning spoken." ${ }^{, 57}$ This meaning not only exists in a sociopolitical context, it belongs to its very fabric.This is why, in addition to phylogenesis and ontogenesis, Fanon also insists on the need for a consideration of the sociogenesis of pathologies. History, and especially colonial history, is expressed in collective complexes. ${ }^{58}$

"The psychic is political"- this is how one might summarize Fanon's position, as long as one does not misuse this catchphrase to trivialize the actual complexity of his theoretical engagement. By employing tools, concepts, and methods from phenomenology and existential philosophy, Fanon already in his earliest work offers a description and analysis of the alienated self in racist societies and of the "epidermalization of inferiority" as an incorporation and internalization of the omnipresent colonial gaze. This incorporation eventually results in an inhibited body schema which objectifies and immobilizes one's own lived body. Fanon will not forget these theoretical analyses when he starts practicing as a psychiatrist at the asylum of Saint-Alban-sur-Limagnole from 1952-1953. To the contrary, he remains very much aware of the connection between colonial and institutional power, as they are manifest in interpersonal relations and experiences. The concepts of power, gaze, alienation, and depersonalization remain important for him-but so do their positive counterparts of freedom, existence, relationality, and empathy. Recent publications have done much to upend the customary view of Fanon as a "conventional" psychiatrist whose political consciousness only unfolded apart from the clinical work in his anti-colonial revolutionary activities. ${ }^{59}$ Rather, both occupations have to be seen in close connection. At Saint-Alban, Fanon came into contact with the "social therapy" or "institutional psychotherapy" that had been developed by Francois Tosquelles and Jean Oury in response to the appalling conditions of psychiatric hospitals before and especially during the Vichy period in France. (A few years later, social/institutional therapy was also to exert an important influence on Basaglia.) Based on humanistic and communitarian principles, the main idea was that the "concentrationist logic"- to use an expression of Tosquelles-of the asylums was to be broken. ${ }^{60}$ The psychiatric hospital should henceforth be understood as a "therapeutic community," where the double alienation of the patients, by their mental illness and by the institutional framework, should be treated jointly. To that extent, it was also the "institution" itself that needed "therapy." Once again, we find phenomenological elements in institutional psychotherapy, be it through its reference to an "epoché"

\footnotetext{
56 Gibson \& Beneduce (2017, p. 42).

57 Fanon (2014, p. 61).

58 Fanon (2008, p. 130).

59 See the foreword by Fanon's colleague and biographer Alice Cherki, in Gibson \& Beneduce (2017, p. ix), Gibson \& Beneduce (2017, p. 21), and Robcis (2020).

60 See Robcis (2020, p. 305).
} 
in relation to conventional psychiatric theories or through the engagement with the patient's experiences and mode of being-in-the-world. ${ }^{61}$ In terms of therapy, particular emphasis was put on group therapy and collective forms of restoring meaning to a patient's "lost" identity. ${ }^{62}$ Hence, all kinds of joint activities by patients and caregivers, including clubs, cafés, libraries, workshops and other social spaces and cultural activities (film, cinema, theater), were encouraged to strengthen the social fabric. At the same time, patients could move around freely and were also allowed to leave the clinic. ${ }^{63}$

The experience at Saint-Alban was crucial for Fanon's subsequent work in 1953-1956 as chief physician at the Blida-Joinville psychiatric hospital in Algeria. As he had already done at Saint-Alban, Fanon enthusiastically organized daily meetings and excursions, set up occupational therapy groups and a library, showed films, encouraged sports, theater groups, and communal singing, and also devoted particular attention to training nurses in the spirit of an institution that first had to treat itself. ${ }^{64}$ However, the colonial situation in Algeria and the French project of a "colonial medicine" - "modernizing while racializing, reforming while conservative"-soon made its limitations felt. ${ }^{65}$

Fanon quickly became aware of his own Eurocentric presuppositions in reforming the "social architecture" of the clinical practice. The Muslim patients (Fanon was in charge of one wing with European women and three pavilions with MuslimArab men) hardly responded to his social-therapeutic program, since, as it turned out, the proposed activities and content remained too "Western," and consequently only served to alienate them further. In a joint article with one of his doctoral assistants, Jacques Azoulay, Fanon describes how these "methodological difficulties" led them to travel through Algeria with the goal of learning more about the cultural forms and social activities of the very country where the hospital was located. On the basis of these travels, Fanon established a café maure in the psychiatric hospital, he ensured that Muslim holidays were celebrated, he selected and showed different kinds of movies and even hired a professional Arab storyteller. Increasingly aware that psychiatry, even in the guise of social therapy, continued the violent colonial cultural assimilation and alienation, Fanon eventually moved "from a phenomenology of oppression to a critical ethnopsychiatry." ${ }^{, 66}$ A few years earlier, in a text on the "North African Syndrome," Fanon had already criticized the racializing strategies of colonial psychiatry, with its denigrating stereotypes and reference to "suspect black

\footnotetext{
61 Naudin \& Goze (2016, p. 35).

62 Doan, de Freitas \& Gargot (2017).

63 In the paper "Day hospitalization in Psychiatry: Its Values and Limitations," Fanon reflects on the topic of an open psychiatry quite sympathetically, but critically (2014, pp. 119-144).

64 See Robcis (2020, p. 317) and Gibson \& Beneduce (2017, p. xii): "To this day, former nurses who worked with 'Dr. Fanon' at Blida- Joinville Hospital in Algeria, still remark on their change of status: they stopped being repressive guards, and became instead active agents in their relationship with the alienated person."

65 Robcis (2020, p. 315). See also Keller (2007, p. 48).

66 See Beneduce (2014, pp. 155-184).
} 
or Arab bodies." 67 Now, he pursued this criticism in a more productive manner, by developing methods of his own that allowed him to integrate elements of the colonized patients' own culture into the therapy.

If psychiatry is to provide, as Fanon envisioned, a "relational, personal, and institutional context that favored the emergence of speech and the retrieval of fragments of histories suffered, silenced, forgotten, and especially censored," it must decolonize itself. ${ }^{68}$ Eventually, however, the project failed. Not only because of hardened colonial structures but also because of the unfolding Algerian War. In his resignation letter from 1956 to the French prefect of Algeria, Robert Lacoste, Fanon described the hopelessness of his enterprise:

For close to three years, I put myself wholly at the service of this country and its inhabitants. I spared neither effort nor enthusiasm. Not one of my actions [...] did not set as horizon the unanimously desired emergence of a decent world.

But what good are enthusiasm and care for the human if reality is spun of lies, cowardice, and contempt for the human on a daily basis?

What good are intentions if their incarnation is made impossible by indigence of the heart, sterility of the mind, and hate for the natives of this country?

Madness is one of the means by which man can lose his freedom. And, I can say that, from the crossroads where I stand, I have measured with horror the magnitude of alienation in the inhabitants of this country.

If psychiatry is the medical technique that proposes to help man no longer be a stranger to his environment, I can only but confirm that the Arab-permanently alienated within his own country-lives in a state of absolute depersonalization. $^{69}$

Franco Basaglia's colleagues in Gorizia quoted this letter in their protest letter from 1972, when they themselves ended their work at the asylum and resigned. ${ }^{70}$

For Fanon himself, the project of reforming the institution of psychiatry under colonial conditions had failed and the anti-colonial struggle had become necessary - though he continued to practice medicine and treat war trauma. As Robcis writes, Fanon learned from existentialism and anthropology "the importance of relationality in the construction of the self. Through Marxism, he came to appreciate the decisive effect of politics on the human condition. Psychoanalysis and phenomenology offered him a theory of embodiment that complemented social construction."71

\footnotetext{
67 Fanon (2014, pp. 41-50). See also Gibson \& Beneduce (2017, pp. 69, 121-130).

68 Cherki in Gibson \& Beneduce (2017, p. 10).

69 Fanon (2014, pp. 113-114).

70 Basaglia himself had resigned already in 1968. He also knew Fanon's publications and cited them appreciatively (Foot 2019, 170). The spirit of Fanon and Basaglia is still alive in Italy today, more precisely in Turin, where the "Centro Frantz Fanon," an association of professionals from the medical-psychiatric, psychological and cultural-anthropological fields, offers counseling, psychotherapy and psychosocial support for migrants, refugees and victims of torture, cf. https://associazionefanon.it.

71 Robcis (2020, pp. 306-307).
} 
But equally, Fanon had to move beyond all these theoretical influences and transform them in his exploration of new practices and strategies of decolonization.

\section{Elements of phenomenological critique}

This brief survey of some parts of the history of phenomenological psychiatry can hopefully make it clear that phenomenology has been "critical" for a long time. The accusation that phenomenology because of its very method is incapable of offering social criticism is simply wrong. This does not equal the claim that phenomenological methods would always be the best ones for any critical endeavor. ${ }^{72}$ They have a certain scope and certain points of focus which, in the case of psychiatry, have proven to be especially suitable and useful. Let us therefore, by way of conclusion, try to summarize in a slightly more systematic way, the different types of critical phenomenological inquiry we have discussed above. They can stand, we think, as exemplary for phenomenological types of critique.

First of all, there is a very "classical" strand of phenomenological argumentation, which opposes all forms of scientism, reductionism and objectivism, and seeks to do justice to the richness of the phenomena by attending to the "things themselves." In the field of psychiatry, this strand is particularly evident in the work of Jaspers and Minkowski and in their attempt to replace a brain-centered approach with a focus on our (inter-)bodily being-in-the-world. This criticism of reductionism is theoretically motivated, but the effort to give voice to experiences that elude the typicality of normality also has ethical and political consequences.

Let us add that the attempt to employ phenomenological insights pertaining to the structures of intentionality, embodiment, temporality, etc. in clinical practice is by no means a thing of the past. Although psychiatry since the time of Jaspers and Minkowski has only become ever more oriented towards naturalism and neurobiology, phenomenological psychiatry remains a living tradition. It has undergone something of a revival during the last 25 years, and is increasingly impacting mainstream psychiatry. ${ }^{73}$ As an editorial in the March 2021 issue of The Lancet Psychiatry put it,

Implicit in any phenomenological project in psychiatry or psychology is a shift in patient state from object of study to subject whose perceptions and experiences are heard, accepted, and valued. This approach could redress power imbalances, and generate collaborative projects in which all parties bring equally valued perspectives. Phenomenology cannot be the sole basis for mental health research. However, a greater number of dedicated investigations, and addition of a phenomenological dimension to larger projects, has the potential to advance — or at least unstick—multiple areas of mental health. There is no

\footnotetext{
72 Some issues - for example, complex and abstract institutional systems (think of European law or globalized capitalism) — are probably better addressed by other approaches.

73 Leading figures in contemporary phenomenological psychiatry include Josef Parnas, Louis Sass, Giovanni Stanghellini, Thomas Fuchs, and others (for an overview see Stanghellini et. al. (2019).
} 
call to discard wholesale conceptual frameworks or the accumulated body of knowledge. But it is time to return to the things themselves. ${ }^{74}$

A milestone event in this revival was the publication in 2005 of a qualitative semi-structured psychometric checklist called EASE (Examination of Anomalous Self-Experience). The checklist, which drew on many years of clinical work and was inspired and informed by ideas found in philosophical phenomenology, was designed to support a systematic clinical exploration and comprehensive assessment of subtle disturbances of subjective experiences. ${ }^{75}$ Phenomenological resources have likewise been used to critically revise and clarify basic psychopathological concepts, including the notions of psychosis, delusion, and hallucination. ${ }^{76}$ During the last few years, there have also been attempts to translate insights from EASE research on self-disorders and phenomenological psychopathology into psychotherapeutic practice. ${ }^{77}$ A guiding idea has been that a careful psychopathological interview can offer the psychiatrist a better understanding of the patient's altered experiential and existential situation which in turn is a necessary precondition for sound psychotherapy. It is noteworthy that patients interviewed on the basis of the EASE scale often express feelings of relief when realizing that the interviewer is familiar with the nature of their experiences and that others suffer from similar experiences. This in itself can make the experiences less frightening and disturbing. The very fact of being listened to and taken seriously consequently has therapeutic value, and often patients who have been in treatment for years wonder why nobody has ever asked them these types of questions before.

By pointing to the impact that a phenomenologically informed anti-reductionistic psychiatry has had on diagnostic and therapeutic work, we are already moving towards the second level of phenomenological critique, which no longer simply concerns scientific and descriptive categories and analyses. Rather, the therapeutic concern for and interest in the otherness of the patient's experience makes the therapist-patient relationship crucial and places the emphasis on the ethics of the concrete interpersonal relationship. We consequently consider it a distinctive strength of the phenomenological approach that it doesn't merely speak out against scientific attempts to reify the other, but as a result of its commitment to respect and understand the subjective perspective of the other, also promotes an ethically responsive dialogue.

This in turn leads to a focus on and broader critique of the coercive structures of the psychiatric institution, of the way in which power is executed in the psychiatric assessment, diagnosis, and therapy. As our discussions of Laing, Goffman, Basaglia and Fanon have shown, phenomenology also engages with these larger institutional and political questions. Laing's political diagnosis, that there is something wrong

\footnotetext{
74 Boyce (2021, p. 169).

75 Parnas et al. (2005). The EASE scale, which in the meantime has been translated into more than 10 languages, has generated a broader interest in not only schizophrenia spectrum disorders but also in phenomenological psychopathology.

76 Parnas (2004, p. 2015), Henriksen et al. (2015).

77 Škodlar \& Henriksen (2019).
} 
with a world that allows for such a violent "politics of experience" of dubious "normalization" and alienation has not lost its relevance. His diagnosis is even more saliently articulated by Fanon, who emphasizes how colonial practices generate alienation and distorted social relationships. In all these cases, ideas from phenomenology are fused with other theoretical perspectives, including Marxism, discourse theory, and anti- or postcolonial theorizing. But again, one of the distinctive contributions of the phenomenological approach is its focus on how power structures manifest themselves on the concrete level of the lived body and self-experience, a dimension that otherwise easily remains "mute." Rather than "merely" criticizing systemic structures and anonymizing and reifying discourses, there is always an interest in and concern for the concrete individual and his or her existential situation. As a psychiatrist, Fanon was not merely seeking to diagnostically classify the other's experience but was precisely seeking to let the other speak; he was attempting to give the patient and the colonized a voice. ${ }^{78}$ Today, Fanon is a recognized figure in critical phenomenology, even if his role in psychiatry might not yet have been appreciated as thoroughly as his anticolonial and antiracist contributions. More than that, he is part of a long history of critical approaches in psychopathology and psychiatry, which has firm roots in the phenomenological tradition, and which keeps up its critical work today.

Acknowledgements We are grateful to Mads Gram Henriksen, Anthony Fernandez, and Maja Zandersen for helpful comments to an earlier version of the present text.

Open Access This article is licensed under a Creative Commons Attribution 4.0 International License, which permits use, sharing, adaptation, distribution and reproduction in any medium or format, as long as you give appropriate credit to the original author(s) and the source, provide a link to the Creative Commons licence, and indicate if changes were made. The images or other third party material in this article are included in the article's Creative Commons licence, unless indicated otherwise in a credit line to the material. If material is not included in the article's Creative Commons licence and your intended use is not permitted by statutory regulation or exceeds the permitted use, you will need to obtain permission directly from the copyright holder. To view a copy of this licence, visit http://creativecommons.org/licen ses/by/4.0/.

\section{References}

Adorno, Theodor W. 1973. The Jargon of Authenticity. Trans. K. Tarnowski and F. Will, Evanston, IL: Northwestern University Press.

Adorno, Theodor W. 2013. Against Epistemology: A Metacritique. Studies in Husserl and the Phenomenological Antinomies. Trans. W. Domingo. Cambridge, UK: Polity Press.

Ahmed, Sara. 2006. Queer Phenomenology: Orientations, Objects, Others. Durham: Duke University Press.

\footnotetext{
78 To continue that tradition, one could imagine that the rich concepts of contemporary critical phenomenology such as "misfitting" or "world-travelling" (see Weiss, Murphy \& Salamon 2020, pp. 225-230, 343-350) might also find their way into psychiatry and psychopathology, and for instance help address mental health issues related to migration or refuge.
} 
Al-Saji, Alia. 2014. A Phenomenology of Hesitation: Interrupting Racializing Habits of Seeing. In Living Alterities: Phenomenology, Embodiment, and Race, ed. E. Lee, 133-172. Albany: State University of New York Press.

Beneduce, Robert. 2014. Afterword. Frantz Fanon: From a Phenomenology of Oppression to the Birth of a Critical Ethnopsychiatry. In Frantz Fanon, Decolonizing Madness: The Psychiatric Writings of Frantz Fanon, eds. N. Gibson and R. Beneduce, 155-184. London: Palgrave Macmillan.

Blankenburg, Wolfgang. 1979. Phänomenologische Epoché und Psychopathologie. In Alfred Schütz und die Idee des Alltags in den Sozialwissenschaften, ed. W.M. Sprondel and R. Grathoff, 125-139. Stuttgart: Enke.

Bloch, Ernst. 1996. Natural Law and Human Dignity, trans. by D. J. Schmidt. Cambridge, Mass.: MIT Press.

Boyce, Niall. 2021. Editorial. The Lancet Psychiatry 8 (3): 169.

Crossley, Nick. 1998. R.D. Laing and the British Anti-Psychiatry Movement: A Socio-historical Analysis. Social Science \& Medicine 47/7: 877-889.

Doan, Kim, David de Freitas \& Thomas Gargot. 2017. Institutional Psychotherapy. In EFPT Psychotherapy Guidebook (2nd ed.). https://doi.org/10.21428/fc0b32aa.19d22c72

Fanon, Frantz. 2014. Decolonizing Madness: The Psychiatric Writings of Frantz Fanon, ed. N. Gibson, trans. L. Damon. London: Palgrave Macmillan.

Fanon, Frantz. 2008. Black Skin, White Masks. Trans. R. Philcox, New York: Grove Books.

Fernandez, Anthony V. 2020. From Phenomenological Psychopathology to Neurodiversity and Mad Pride: Reflections on Prejudice. Puncta. Journal of Critical Phenomenology 3 (2): 19-22.

Foot, John. 2015. The Man who Closed the Asylums: Franco Basaglia and the Revolution in Mental Health Care. London: Verso.

Foot, John. 2019. Franco Basaglia. In The Oxford Handbook of Phenomenological Psychopathology, ed. G. Stanghellini, M. Broome, A. Raballo, A.V. Fernandez, P. Fusar-Poli, and R. Rosfort, 165-172. Oxford: Oxford University Press.

Foucault, Michel. 2007. What is Critique? In The Politics of Truth, ed. by S. Lotringer, introduction by J. Rajchman, trans. L. Hochroth, Los Angeles: Semiotext(e), 42-81.

Gibson, Nigel G. \& Roberto Beneduce. 2017. Frantz Fanon, Psychiatry and Politics. London/New York: Rowman and Littlefield.

Goffman, Erving. 1961. Asylums: Essays on the Social Situation of Mental Patients and Other Inmates. New York: Anchor Books.

Gündoğdu, Ayten. 2015. Rightlessness in an Age of Rights: Hannah Arendt and the Contemporary Struggles of Migrants. New York: Oxford University Press.

Günther, Lisa. 2013. Solitary Confinement. Social Death and its Afterlives. Minneapolis: University of Minnesota Press.

Hacking, Ian. 2004. Between Michel Foucault and Erving Goffman: Between Discourse in the Abstract and Face-to-Face Interaction. Economy and Society 33 (3): 277-302.

Henriksen, Mads G., Andrea Raballo, and Josef Parnas. 2015. The Pathogenesis of Auditory Verbal Hallucinations in Schizophrenia: A Clinical-Phenomenological Account. Philosophy, Psychiatry, \& Psychology 22 (3): 165-181.

Insel, Thomas, Bruce Cuthbert, Marjorie Garvey, Robert Heinssen, Daniel S. Pine, Kevin Quinn, Charles Sanislow, and Philip Wang. 2010. Research Domain Criteria (RDoC): Toward a New Classification Framework for Research on Mental Disorders. The American Journal of Psychiatry 167 (7): 748-751.

Jaspers, Karl. 1912. Die phänomenologische Forschungsrichtung in der Psychopathologie. Zeitschrift für die gesamte Neurologie und Psychiatrie 9: 391-408.

Jaspers, Karl. 1963. General Psychopathology, trans. J. Hoenig \& M.W. Hamilton Chicago: University of Chicago Press.

Keller, Richard C. 2007. Colonial Madness: Psychiatry in French North Africa. Chicago: University of Chicago Press.

Kraepelin, Emil. 1913. Lehrbuch der Psychiatrie, 8th ed. Leipzig: JA Barth.

Laing, Ronald D. 1960. The Development of Existential Analysis. A Paper given to RMPA, December 1960. MS Laing A116-7.

Laing, Ronald D. 1963. Minkowski and Schizophrenia. Review of Existential Psychology and Psychiatry 3 (3): 195-207.

Laing, Ronald D. 1967. The Politics of Experience and The Bird of Paradise. Harmondsworth: Penguin.

Laing, Ronald D. 1990. The Divided Self. Harmondsworth: Penguin. 
Laing, Ronald D., and David G. Cooper. 1964. Reason and Violence: A Decade of Sartre's Philosophy, 1950-1960. London: Tavistock Publications.

Loidolt, Sophie. 2021. Order, Experience, and Critique: The Phenomenological Method in Political and Legal Theory. Continental Philosophy Review 54 (2): 153-170.

Lovell, Anne M. \& Nancy Scheper-Hughes. 1987. Introduction. The Utopia of Reality: Franco Basaglia and the Practice of a Democratic Psychiatry. In Psychiatry Inside Out: Selected Writings of Franco Basaglia, eds. A.M. Lovell \& N. Scheper-Hughes, 1-50. New York: Columbia University Press.

Luxon, Nancy. 2021. Fanon's Psychiatric hospital as a Waystation to Freedom. Theory, Culture \& Society. https://doi.org/10.1177/0263276420981612.

Minkowski, Eugène. 1970. Lived Time: Phenomenological and Psychopathological Studies. Evanston: Northwestern University Press.

Naudin, Jean, and Tudi Goze. 2016. Psychothérapie institutionnelle et phénoménologie. Sud/nord 26 (1): 33-42.

Oksala, Johanna. 2005. Foucault on Freedom. Cambridge: Cambridge University Press.

Oksala, Johanna. 2016. Feminist Experiences. Foucauldian and Phenomenological Investigations. Evanston: Northwestern University Press.

Ortega, Mariana. 2016. In-between: Latina Feminist Phenomenology, Multiplicity, and the Self. Albany: State University of New York Press.

Parnas, Josef. 2004. Belief and Pathology of Self-Awareness: A Phenomenological Contribution to the Classification of Delusions. Journal of Consciousness Studies 11: 148-161.

Parnas, Josef. 2015. Philosophical and Phenomenological Perspectives on Psychosis. In The Assessment of Psychosis: A Reference Book and Rating Scales for Research and Practice, ed. F. Waters and M. Stephane, 17-43. New York: Routledge.

Parnas, Josef, Paul Møller, Tilo Kircher, Jørgen. Thalbitzer, Lennart Jansson, Peter Handest, and Dan Zahavi. 2005. EASE: Examination of Anomalous Self-Experience. Psychopathology 38 (5): 236-258.

Parsons, Talcott. 1968. Interaction. In Encyclopedia of the Social Sciences, ed. D.L. Sills. New York: Macmillan.

Psathas, George. 1989. Phenomenology and Sociology. Lanham, MD.: University Press of America.

Robcis, Camille. 2020. Frantz Fanon, Institutional Psychotherapy, and the Decolonization of Psychiatry. Journal of the History of Ideas 81 (2): 303-325.

Schmidgen, Henning. 2003. Lacan und die Phänomenologie. Österreichische Zeitschrift für Geschichtswissenschaften 14 (2): 108-132.

Serapioni, Mauro. 2019. Franco Basaglia: Biography of a Revolutionary. História, Ciências, Saúde Manguinhos 26/4: 1-18.

Škodlar, Borut, and Mads G. Henriksen. 2019. Toward a Phenomenological Psychotherapy for Schizophrenia. Psychopathology 52: 117-125.

Smith, Gregory W.H.. 2006. Enacted Others: Specifying Goffman's Phenomenological Omissions and Sociological Accomplishments. Human Studies 28: 387-415.

Stanghellini, Giovanni, Matthew Broome, Andrea Raballo, Anthony V. Fernandez, Paolo Fusar-Poli, and René Rosfort, eds. 2019. The Oxford Handbook of Phenomenological Psychopathology. Oxford: Oxford University Press.

Weinstein, Raymond W. 1994. Goffman's Asylums and the Total Institution Model of Mental Hospitals. Psychiatry 57: 348-367.

Weiss, Gail, Ann V. Murphy, and Gayle Salamon, eds. 2020. 50 Concepts for a Critical Phenomenology. Evanston, IL: Northwestern University Press.

Zahavi, Dan. 2021. Applied Phenomenology: Why it is Safe to Ignore the Epoché. Continental Philosophy Review 54 (2): 259-273.

Publisher's Note Springer Nature remains neutral with regard to jurisdictional claims in published maps and institutional affiliations. 